\title{
MANNING'S ULTRAMONTANISM AND THE CATHOLIC CHURCH IN BRITISH POLITICS
}

Jeffrey P. von Arx

Fairfield University, president@fairfield.edu

Follow this and additional works at: https://digitalcommons.fairfield.edu/history-facultypubs

Copyright 1989 Catholic Record Society http://www.catholicrecordsociety.co.uk Recusant History http://www.catholicrecordsociety.co.uk/recusant-history

\section{Peer Reviewed}

\section{Repository Citation}

von Arx, Jeffrey P., "MANNING'S ULTRAMONTANISM AND THE CATHOLIC CHURCH IN BRITISH POLITICS" (1989). History Faculty Publications. 33.

https://digitalcommons.fairfield.edu/history-facultypubs/33

\section{Published Citation}

von Arx S.J., Jeffrey P. "MANNING'S ULTRAMONTANISM AND THE CATHOLIC CHURCH IN BRITISH POLITICS". Recusant History; May1989, Vol. 19 Issue 3, p332-347, 16p

This item has been accepted for inclusion in DigitalCommons@Fairfield by an authorized administrator of DigitalCommons@Fairfield. It is brought to you by DigitalCommons@Fairfield with permission from the rightsholder(s) and is protected by copyright and/or related rights. You are free to use this item in any way that is permitted by the copyright and related rights legislation that applies to your use. For other uses, you need to obtain permission from the rights-holder(s) directly, unless additional rights are indicated by a Creative Commons license in the record and/or on the work itself. For more information, please contact digitalcommons@fairfield.edu. 


\section{MANNING'S ULTRAMONTANISM AND THE CATHOLIC CHURCH IN BRITISH POLITICS}

\author{
by JEFFREY P. VON ARX, S. J.
}

A FTER his conversion to Roman Catholicism, the first major invontroversy in which Henry Edward Manning found himsel involved as a member of his new church concerned the Roman Question or the Temporal Power: that is, the political status and future of the Papal States. Now the question of the temporal power of the pope and the amount of controversy it engendered, is one of those issues in nineteenth century church history whose significance it is difficult for us to understand. By the mid-nineteenth century, especially in relation to the movement for Italian unification, the temporal power of the popes looks to us like an historical anachronism. To Roman Catholic today, it is obvious that the ability of the church to preach the gospel has been enhanced and its mission in the world correspondingly facilitated by being disembarrassed of the burden of political control in central Italy. How to explain, then, the tremendous controversy the Roman Question aroused over so long a period in the second half of the nineteenth century, and the conviction, especially of the papacy's defenders, that the preservation of the Papal States was critical for the survival, not only of religion, but, as we shall see, of civilization in the West?

It does not take too great an effort of historical imagination to offer a partial answer to this question, and the evidence is near to hand Henry Manning and many other Roman Catholics were convinced that the temporal power of the popes was necessary for the effective exercise of the spiritual mission of the papacy: the ability to preach the gospel without hindrance. As Manning put it in one of his earliest pronouncements on the subject, the temporal power was 'necessary for the exercise of the spiritual power [of the papacy] in perfect freedom' What Manning and so many other Catholics feared was that the end of the temporal power would make more difficult the pope's, and hence the Church's, freedom of action. It really mattered little who would take over the Papal States: whether the Austrians, the Piedmontese or Garibaldi's republicans. In any case the pope would be subject to a secular ruler, and Manning feared from his Anglican experience the consequences for the papacy of domination by the State.

We know in hindsight that such fears were groundless; or rather, that the sovereignty the pope required for the freedom of the Church was a personal, not a territorial one, the Vatican City State recognized by the Lateran Treaty of 1929 being little more than a geometric point. by the Lould himself eventually come round to this position, and Manning would hims accommodation with the Italian government urge upon the papacy an accommo until decades later. And so we the papacy was not prepared to make until decades later. And the temporal power as a are tempted to dismiss the whole problem of the temporal power as a
tempest in a teapot, or one of those dead ends in history which it is not particualarly profitable to pursue.

We do so, however, only by ignoring a whole other dimension of We do so, however of the temporal power that, in the early 1860 's, the case in favour of the temporal power that, in the early 1860's, Manning and other ultramontanes considered even more important than the argument about the spiritual freedom of the Church. Manning
believed the Church and the papacy could survive the loss of the believed the Church ar a church to preach the gospel was concerned, would even thrive under the to preach the gost might entail. But what would be destroyed by persecution this loss might entail. But what would be dhe Church, but what Manning loss of the the world', or, from another termed alternately thicising mission of the Church'. ${ }^{2}$ It was the possibility perspective, the 'civilising mission of the Church". It was the possibility of this latter consequence, that formed, from Manning's point of view, the strongest argument in favor of the continuance of the temporal power.

What did Manning mean by the 'Christian order of the world,' and the 'civilising mission of the Church,' for whose preservation the the civilising istionct temporal power was essential, as distinct from its spirtual mission? And what did these concepts have to do with the principles of church order-authority, the unity of the Church, the freedom of the Church from secular interference-for which he had abandoned the church of his birth to join the Roman communion?

The argument about the 'Christian order of the world' and the 'civilising mission of the Church' had to do with the normative relation'civilising mission of the Church' had to do with the normative relationIt was the role of the Church, Manning maintained, to change, to transform, to unify, to organize individuals, families, cities, and nations to create a social order that, in all its aspects, explicitly acknowledged the truth of Christian faith, and bound itself to follow the precepts of Christian morality. ${ }^{3}$ Such a society would be, of course, something different from-Manning would have said superior to-natural civil society, what we would call secular society. What Manning had in view was the medieval vision of the Christian commonwealth, or Christendom, in which church and state pursued a common goal, and that a supernatural one: the sanctification of men and women in this life unto their salvation in the next. Church and State pursued this goal by different means, and each in its own sphere; but because the ultimate goal or finality of Christian society was a spiritual one, it was inevitably the Church that provided leadership, direction, admonition and correction in this pursuit. In the ideal state of affairs, Manning would write, 
Church and State stood 'in relations of mutual recognition, amity an cooperation, "but it was the responsibility of the Church to 'elevate direct, sanctify and consolidate the civil order which we call the State ', $^{4}$

It was obvious that in order to perform this function for the State the Church had to be, in the first instance, absolutely free and unfettered by any restraint on the part of the State in what was essential to it spiritual mission. But in addition, the Church must have the ability to engage civil society in some effective way. The papacy, Manning had recognized in the course of his conversion, was the divinely instituted principle and guarantee of the Church's freedom and autonomy. Respect for the temporal power, therefore, signifying as it did recognition o the sovereignty of the pope, was the condition of possibility for the complex and traditional set of relations between Papacy and States that constituted this engagement. If Christianity were to be realized within the order of civil society, it was the Church's-but preeminently the pope's-ability or inability to engage civil society freely and effectively that would make a society Christian or not. In the early 1860's, it was still Manning's conviction that the temporal power of the papacy was the indispensable condition for this engagement and therefore part of the divine dispensation for the Church. ${ }^{5}$ Without the temporal power and the whole system of official relations and explicit agreements between the papacy and European States that presupposed it, Manning and most other ultramontanes did not see how the Church could continue to play its proper role in civil society, or how any international order in which the rights of the papacy and of the Church were not recognized could be called Christian. ${ }^{6}$

Manning, however, could read the signs of the times, and as soon as his earliest pronouncements on the temporal power, he shows himself to have been aware that the lack of support for the temporal power on the part of most European governments, plus the threat of Italian revolutionary nationalism meant the pope's rule over the Papal States did not have long to survive. But the termination of that rule, as the end of the conflict between the Modern State and the Catholic Church, Manning wrote in 1861, would be to 'desecrate the civil powers of the world."

What Manning thought would be the consequence of this desecration is rather unclear in the early 60 's. In the essay we have been quoting, which offers his most developed thought on the question of the temporal power at this time (The Temporal Power of the Vicar of Jesus Christ, published in 1862), Manning begins by offering what would appear to be fairly neutral, analytic descriptions of a desecrated state as one that does 'not acknowledge any form of faith as obligation upon its conscience, ${ }^{8}$ and of desecration as 'the removal of the order of social life from the supernatural to the natural order;, ${ }^{9} \mathrm{He}$ gives as an example of desecration and its consequences the introduction of divorce by the French Republic in 1793, with the consequent dramatic increase in divorce in that country: ${ }^{10}$ surely not a development that Manning approved, but ald describe by less loaded words like secularization or desacralization.

What is most striking, however, about Manning's perception in the
desalization. What is of the effects of the wholesale desecration that would follow the abolition of the temporal power was the (melo)dramatic scenario the abolition of the temporal power was the (melo)dramatic scenario the world shall desecrate themselves [by abolishing the temporal power] the world lose thelation to Christianity, they will inaugurate the beginning and lose their relation to Che Antichrist shall come." ${ }^{11}$

This recourse to apocalyptic (which incidentally involved Manning in some trouble at Rome), ${ }^{12}$ presents a problem for the historian trying to some trouble at Rome), ${ }^{12}$ presents a problem for the historian trying to at least an intelligible definition and description of what we would call the desacralization of the State, that Manning lapses into extravagant the desacralization of the State, that Mands of response are possible. On one level, a fairly obvious one, one can say that whatever contemporary or subsequent estimates of the importance for the Church or the or subsequent estimates of the importance for theral power, it appeared so critically necessary for both, to Manning and others who thought like him, that the real prospect of its loss filled them with such anxiety and dismay as could only find expression in the kind of religious language traditionally reserved for the most critical, desperate hours of the Church's history. But on another and related level, one can make the ultimately more But on another and related level, one can make the ultimated by the fact that at this point, in 1862, Manning did not yet see how the Church would surmount the coming crisis, brought on by the end of the would surmount the coming crisis, brought on by the civil society. Manning's reversion to apocalyptic should be seen, I would argue, as an indication of failure of imagination on his part as to how the Church an indication of fallure of ingilising'mission. But this failure was a defect that would not take long in its amendment, and that amendment provides a new and interesting chapter in the history of ultramontanism.

It was the appearance, or rather, Manning's notice of two new features of the religious landscape of Britain in the next few years that seems to have been responsible for the gradual revision and eventual abandonment of his alarmist views on the dire consequences that would follow in the wake of the abolition of the temporal power. The first of these was a clear perception of the vigour of the Roman Catholic Church world-wide, but especially in England. As he tried to elucidate for a Catholic audience the critical character of the age in a lecture delivered to the Academia of the Catholic Religion in 1863, Manning noted as signs of the times not only the growth of unbelief, but also the growing effectiveness of Catholic missionary endeavours, the renewal of Catholic strength and action upon the peoples of the old 
Catholic countries of Europe, and finally, 'a disposition among the populations separated from it' [the Roman Catholic Church] to return to it, both in the East, especially in Russian lands, but also 'in the West, [where] a similar movement is in progress, of which England is
visibly the centre..$^{13}$

In a subsequent Address to the same body three years later, Manning picked up this theme again, with special reference to England, noting the 'disproportionate influence exercised by the Catholic Church in England upon society, when compared with the narrow material presence of the Church and its signal disadvantages of poverty and obscurity. ${ }^{14}$

A second feature of the religious landscape that Manning cites as indicative of the critical character of the time and which he presented to his listeners in the 1863 address was somewhat connected with the resurgence of Roman Catholicism in Britain, but had to do with developments Manning discerned in the Established Church. Here one must proceed cautiously, because Manning's tone in this matter changes over time, and it is perhaps too easy to assume that his comments on Catholic influence in the Church of England are merely an expression of Roman triumphalism. But to treat Manning's remarks on the Church of England in both the 1863 and the 1866 Addresses as instances of triumphalism would be to miss a most important turning point in Manning's thought. For the resolution of the uncertainty about the role of the Roman Catholic Church in the desacralized secular orderan uncertainty that had been responsible for Manning's recourse to apocalyptic-was actually worked out in his mind in terms of developments within the Church of England, the church of his birth. And the change in tone and an alteration of perspective between the 1863 and the 1866 Address indicates a new appreciation of the role of and relationship between the Catholic Church and other religious denominations within the context of a desacralized or secularized public order.

In particular, Manning seems to have been fascinated by the condition and prospects of the Church of England in light of what he considered its effective disestablishment. In the 1863 Address, Manning argues that after the repeal of the Test and Corporations Act (1819) and the granting of Catholic Emancipation (1829), the exclusive political and social monopoly of the Church had been broken, and the Establishment was now thrown upon its own resources. He recognized that the new freedom of action hailed by some within the Church [of England] had, in the last thirty years, brought forth much zeal from its members, and multiplied its churches and ministers. But the loosing of the Establishment's bonds had also served to exacerbate and bring into public view its divisions. The Church was now divided between two schools of thought, which Manning calls the 'Rationalistic' and the 'Romanising.' While again some within the Church claimed theological debates were signs of life, for Manning they were 'rather signs of the cute excitement which precedes dissolution. ${ }^{15}$ Even what Manning calls the 'Romanising' tendency within the Church of England, which might be taken as a sign of rapprochement between the two churches, might only find its providentially intended purpose, he cautioned, with could only find its providentially intended the justice of Catholic doctrine and practice to the Catholic Church. ${ }^{16}$

But in the subsequent Address of 1866 , there is a change of perspective But in the subsequent Address of 1866 , there is a England that I believe signifies a development of his thinking about the way in which religious organizations, including, but not limited to the Roman Catholic Church, together might impact society.

In the 1866 Address, Manning continues to read the signs of the Ines for his audience, and continues to maintain that the age was times for his audience, and continues to maintain that the a tendency to unbelief [that] charction to wide and extending. Nevertheless, the reaction toward faith and constant.' This reaction was quintessentially represented by the and constant.' This reaction was quintessentially represented by the Manning does not limit the reaction toward faith to Catholic resurgence. He also finds evidence of it among Dissenters and Anglicans:

There never was a moment when, notwithstanding all contrary symptoms, the Dissenters were more inclined toward the Establishment, and never a the Dissenters were more inclined toward the inclined towards the [Roman Catholic] Church. I speak of it as an inclination; for I neither expect that Dissenters will be absorbed by Anglicanism, nor Anglicanism by the Catholic Church. The tide, however, is in that direction; and it is a tide of which no law of sufficient force can be found except a momentum of the will and grace of God.

But the return of Catholic truth is not confined to this vague, popular, superficial, and aesthetic fashion of men's minds. It has taken a more definite and energetic form. In the last thirty years there has sprung up in the Anglican Establishment an extensive rejection of Protestantism, and a sincere desire and claim to be Catholic. ${ }^{17}$

Even though he does not see this rapprochement of ecclesial communities in England leading to the reunification of Christians on Rome's terms, which must always be the end for which Catholics aspire, still Manning concludes his observations on 'Romanising' tendencies within the Establishment with the following comments:

On all these things I trust a blessing may descend. I see in them many things. First, they are a testimony in favour of the Catholic Church, which has always unchangeably taught and practised these things; secondly, a testimony against the Anglican Reformation, which has always rejected and cast them out. I joyfully recognize the zeal and piety of those (excepting, I fear, a few) who promote them. I believe for the most part they are sincere, and that multitudes are in an ignorance which is invincible. . .

Now no has ever been borne along by it himself, without a profound sympathy, and a desire to cherish it and direct it with tenderness and fidelity. . . . [T] [Te 
movement as a whole can be regarded no otherwise than as an impulse of the Spirit of God, preparing the hearts of men beforehand for the advance of His Church. .

And now, what attitude ought we to assume towards this aspect of the religion of England?

First, that of hope and kindness: of hope, that it may lead on to better things; and of kindness, lest we should throw back those who are moving upwards and onwards painfully and doubtfully towards a perfect knowledge of the truth. ${ }^{18}$

What is present here, in contrast to the Address of 1863 , is a change not, of course, in Manning's theological position on the status of the Anglican Church or on the need for conversion of individual Anglicans but certainly the change in perspective and tone that is suggested above. Both the Dissenters and the Anglicans are seen not as rivals, but really for the first time as allies with the Roman Catholics in the great contest with unbelief. And Manning's tone toward both groups, and especially toward the 'Romanising' party in the Church of England has ceased to be mainly polemical and controversial, and become much more welcoming and sympathetic.

These changes are important not just because they signify a move toward religious irenicism. For our purposes they are crucial because they point the way toward eventual cooperation with other religious communities in a common political agenda against secularism in the context of a pluralist and, of course, increasingly democratic political culture. And it is, I will argue, in the recognition and pursuit of this agenda that Manning worked out a new and hopeful vision of the role of the Church in a 'desacralized' or secular state.

Now it is an intriguing matter, to which we shall return shortly, that the elaboration of the relation of Church to the new political culture was something that Manning continued to think through in reference first of all to the position of the Anglican Church. In a series of essays, England and Christendom, published in 1867, Manning took up again the subject of what he had by now clearly come to recognize as the revival of the Church of England after the events of 1819 and 1829 'The emancipation of Catholics and Dissenters,' Manning wrote, and the admission of both into the social and public life of England, is morally the disestablishment of the Church of England. It retains its wealth and titles, but its exclusive ascendancy is gone. It is only one of many religious bodies.' 'Nevertheless,' he continued, 'the moral disestablishment of the Anglican system has wrought upon it a great change for the better. It has elicited the zeal, activity, enterprise, inventiveness, generosity which is in the nature of Englishmen and Englishwomen. . . . No one who has a love for souls can look upon this rising of the Spirit of life in the Anglican system without a tender and loving care. I pray God, day by day, to perfect the work which $\mathrm{He}$ has begun and never to stay His hand until He has reunited England to Christendom. ${ }^{19}$
Now if the moral or virtual disestablishment of the Church of Now if the moral or strome of the constraints of state control England had liberated in for more zealous, active age against unbelief, the position of the Roman the great struggle of the age against unbelief, the position of the Rom energies. The Catholic Church was even more suited to lites, but 'the Catholic Church Established Church in absolute poverty, . . . [with] no worldly interests in England comes in absolute poverty, . . . [Its bishops and priests] have not only the independence to serve . . . . but they have the genuine sympathy and self-denying charity of the faithful. ${ }^{20}$

Second, the Catholic Church 'is eminently in England, as the Church of God must always be in all lands, the Church of the poor. It is not of God must always be in all the the Church of the Crown, certainly. It is not the Church of the aristocracy. It is not the Church of the landlords, in Ireland or in England . . . it is the Church of the poor. ${ }^{21}$ Where once the Catholic England . . it is the perceived as something alien, imposed from above by monarchs like Mary Tudor or James II, an exotic growth of foreign provenance, now the Catholic Church in England was 'the of for of Ireland and the poor of England, mingling together, in poverty, labour, mutual kindness and marriages which unite both races in the unity of the Faith.'22

Not only did Manning see an advantage to the Catholic Church and its mission in its poverty and identity with the poor; there were advantages, too, in the fact that the "Catholic Church re-enters England wholly free from all political action or interest. It is not bound up with wholly free from all political action or interest. It is not bound up with any royal house or disputed succession or class legislation or aristocratic privilege or monopoly of power or wealth. It has no politics but the maintenance of legitimate authority and the widest possible beneficence. . . . It has no points of contact, and therefore no points of collision, with the political world. . . . It is manifest, therefore, to the whole English people, that the Catholic Church appeals to it by no power or influence but those of conviction or persuasion. . . . If the Catholic Church can spread itself by fair means, by conviction of the reason and persuasion of the heart, that is, by truth and charity, the people of England will give it a fair field, though no favour. ${ }^{23}$

I will consider in a subsequent part of this study the extent to which these protestations of disinterest in any political influence for the Catholic Church in England were disingenuous on Manning's part. But clearly they indicate a very different vision of the place of the Church in relation to the temporal order than the 'Christian order of the world' resting on the temporal power of the papacy whose impending demise had filled Manning with apocalyptic foreboding in 1861. And it is a different vision not merely in acknowledging the inevitablility of a new set of relations with the State, but different, too, in suggesting, at least implicitly, new opportunities for religious bodies in a desacralized political order. 
Just what kind of relationship might develop between a religious body and the new political order in a country like England, and what the opportunities for a religious body like the Catholic Church might be in the new circumstances of a desacralized political order, Manning continues to explore in 1868 , in the next of his series of Addresses the Academia of the Catholic Religion. Because the Church of England is once again the focus of his attention, one begins to suspect that Manning must have his reasons for posing the problem of the political role of the Church in a secular State with reference to the Anglican Church, rather than the Roman Catholic Church. This displacement may have its explanation in Manning's continued interest in the political fortunes of the Church of his birth: after all, the subject of the [Anglican] Church in relation to the State had been of consuming interest to him during his Anglican career, and was the reason he lef the Church. But one must also wonder about Manning's need to work out the rationale for a new political role for the Church precisely apart from any reference to the Roman Catholic Church.

As Manning himself realized, the teaching of the Catholic Church about the proper relationship between Church and State, most recently reiterated in the Syllabus of Errors (1864), was quite clear, and Manning restates it in the 1868 Address: 'the Church and the State should stand in relations of mutual recognition, amity and cooperation under the supreme direction of the Vicar of Jesus Christ, Pontiff and King. ${ }^{24}$ Even to begin, therefore, to reformulate the Church-State relationship in any direct or explicit way, was to come up against what Manning himself would have considered irreformable teaching of the Church According to Catholic doctrine, it was permissible to entertain other ways of relating to the State only by way of exception, in extenuating circumstances, such as the position of the Church under pagan or heretical rulers. These two only alternatives, of official recognition, usually by concordat, in which the spiritual supremacy of the pope was admitted (a model of Church-State relations usually called 'the thesis' in Catholic discussions of these matters) or of the Church accommodat ing itself of necessity to extraordinary circumstances under a presumably hostile and possibly persecuting regime (a state of affairs called 'the antithesis') left very little room for manoeuvering in a new situation such as that in England, where the State was unlikely ever to enter into official relations of spiritual subordination to the papacy, and yet was showing itself at least neutral, if not, indeed, at times, well-disposed to the Catholic Church.

It might, therefore, have been to give himself more room to think through new models of Church-State relations that Manning continued to focus, in his Addresses to the Academia, on developments within the Establishment. Certainly, this line of thinking did have the effect of generating such a model; and at a later point in this study, I intend to consider concretely and in detail how Manning used the new model redirect political behaviour of the Catholic Church in England without having to confront or challenge directly the classic teaching of the thesis.

he thesis. 1868 Address, Manning once more claims that the Church of In the 1868 Address, Manning once more claims that the Church of England has been 'morally disestablished' by the repeal of the Test and Corporations Act and by Catholic Emancipation, a 'change in our corpory which placed its [the Establishment's] destinies in the hands of a polity which placed its [the Estate in which Dissenters from the State constituency and a legislature in which Dissenters from the State religion form a very powerful element.' But it was the effect, in Manning's view, of that 'moral disestablishment' which commands our attention. For, 'from that day,' he argues, 'the Church of England began to appeal to its own spiritual authority and to exert its own internal energies.' From being an Establishment with exclusive privileges, in a energies. ' From special relationship with the State, coterminous with the political nation, the Church of England had become, in virtue of moral disestablishment, a 'voluntary body',25 that is, it came to occupy, in relation to the State, a 'voluntar the same position as other 'voluntary' religious bodies in England: the Nonconformist denominations and-the Roman Catholic Church.

Church. voluntary religious organization are: 'the multiplication of the churches dependent on voluntary offerings, the founding of schools without endowments, and the multiplication of colonial bishoprics': in other words, the initiatives the Church had taken on its own behalf, and without the aid of the State, to strengthen and build up its own structure, both at home and abroad. But it was not only impact on the internal energies of the Church leading to greater institutional growth that Manning foresaw as a consequence of disestablishment and volunthat Manning foresaw as a consequence of disestabs he turns to prediction and advocacy of legal disestablishment of the State Churches (the Kirk of Scotland, the Church of Ireland and the Church of England), Manning at first reiterates his conviction that if these Churches were legally disestablished tomorrow, "the effect would be to stimulate their internal energies, and to make them exert all the powers that are in them. The religious fervour of the country would certainly be multiplied, and that not in the way of controversy, but in each body or communion upon itself. The three Establishments would somewhat more adequately do their proper work, and the sum of religious zeal and activity in the kingdoms would be increased. ${ }^{26}$ Having thus restated his hopes for the internal regeneration of the churches, Manning goes on to predict the internal regeneration of the churches, Manning goes of the public arena: 'the course of public legislation would assuredly not be less Christian. The public opinion of the country would be more so; and the legislature must ultimately be governed by public opinion. ${ }^{27}$

In other words, so far as the Established Churches in the United Kingdom were concerned, the change in relationship to the State from 
one of official recognition to voluntary status would free them to act more effectively upon public opinion, the electorate, and hence, on Parliament. Such a liberation of the forces of organized Christianity given the structure of British politics, and the new susceptibility of politicians to public opinion-remember Manning is speaking a year after the Reform Act-offered an opening of the political system to the activity of a more, not a less Christian society and government.

Having stated so much about the new opportunities offered to the initiative of Protestants by disestablishment, Manning added that, sit is not my purpose now, and time would forbid me to trace out the effect of all this upon the Catholic Church in this country. ${ }^{28}$ And, as I have suggested, there was good reason for Manning not to do so, as least in any way that would challenge directly the 'thesis' position of the Catholic Church on the proper relationship of Church and State. But having begun to develop a working theory about the new and exciting possibilities open to the churches for Christianizing national life in the circumstances of a 'desecrated' or desacralized public order, Manning could turn to the practical question of how the Catholic Church in particular might achieve these effects.

If, in 1860-61, Manning had lamented the desacralization of the public order as it manifested itself in the attack on the Temporal Power and reacted to this phenomenon with apocalyptic alarm, by 1868 , he saw the same desacralization, as far as England was concerned, as the condition of possibility for a more Christian public life through what is clearly conceived to be the collective action of the churches in the arena of popular politics on a government now virtually admitted to be secular and religiously neutral.

To convince Roman Catholics, however, whether English Roman Catholics traditionally aloof from public life, or Roman Catholics in Italy and France still wedded to the thesis position on the necessity of an official relationship between Church and State, of the licit nature of this new departure in the way Catholics might participate in national political life, Manning would eventually have to address his own co religionists. He would need to do this in a way that did not challenge traditional teaching directly, but still allowed for the kind of opening to active Catholic participation in the public life of the desacralized State that he envisaged. In two pastoral letters issued in anticipation of the Vatican Council, and likely, therefore, to receive a reading among continental as well as British Catholics, Manning confronted the possible objections that ultramontanes in Rome and France were likely to entertain to a new departure in Catholic political action. In his 1867 pastoral, 'The Centenary of Saint Peter and the General Council,' Manning began by advising his fellow Catholics, in language calculated to disarm conservative Catholic critics, that 'the day seems to be past for the Church to unite itself with the civil state of modern nations. They have shattered the unity of religion, and broken up the public law, to conform it to their religious divisions. Over such mixed States, the Church has little disposition to assume control. They are States, the Church has little disposition to assume control. They are too alimal and replete with moral and spiritual dangers, is an established fact in the larger part of the modern world. The Church can at least draw from it the advantage, that if the State will no longer invite it to serve the people, its own spiritual action is left free and pure. ${ }^{29}$

And how would the Church exercise that spiritual action? If governments would no longer listen to the Vicar of Jesus Christ, "the people will. And this, it would seem, may be the future. The pastors know their flocks, and their flocks know them... the instincts of the masses are Christian, and the tendency of political society is everywhere to the people. Of this we have no fear. The Church is nowhere so vigorous than where it is in closest sympathy with the people; as in Ireland and Poland, in America, Australia and England. ${ }^{30}$ One of the reat advantages that Manning expected from the Council just lately convoked by Pius IX was that it would both clarify these issues and itself provide an example of 'the supreme spiritual independence of the Church convened by its head, without dependence on any civil power, freely legislating for the whole Catholic unity [which example] must appeal to every pure instinct of Christians. ${ }^{3}$

But if Manning were to vindicate the possibility of independent action in the new environment of the liberal secular State, perhaps the most critical opposition among Catholics that would need to be overcome was the objection of French ultramontanes that the liberal State, based as it was on the principles of the Revolution of 1789 , was not only a departure from the ideal of Church-State relations, but was inimical in its very foundations to the existence and mission of the Church, such that implacable hostility, or, at the very best, complete non-participation was the only permissible attitude of true Catholics to such a State. In consequence, there was in France agitation among anti-clerical liberal politicians for government intervention to prevent or to control the Council, on the grounds that anticipated pronouncements about papal infallibility might further erode the loyalty of French Catholics to the imperial regime. The Syllabus of Errors was offered as evidence that the tendency of ultramontane Catholics was opposed to modern liberties and modern forms of government, and, of course, the rhetoric of French ultamontanism in the person of Louis Veuillot fuelled such arguments. In his Pastoral Letter of 1869, 'The Oecumenical Council and the Infallibility of the Roman Pontiff,' it was, therefore, part of Manning's agenda to clarify the interest and concern that European States should have in the impending Council.

In such an atmosphere, Manning needed on the one hand to convince English Roman Catholics that they should take advantage of the openings offered to voluntary religious organizations in the environment of a secular democratic State to undertake political action. On the other 
hand, it was important to convince liberal politicians, in England an elsewhere, that they had nothing to fear from the impending Council, whose witness and decisions Manning was convinced would make that action all the more striking and effective.

And so it is when we turn to the 1869 Pastoral that we find Manning making an argument that to most French ultramontanes must have seemed in the highest degree false, offensive and perverse. In commenting on the agitation in the Corps Legislatif and in the French press against the Council on the grounds that the Syllabus already proved the Church an enemy of the heritage French politics and government owed to the Revolution, Manning observed: 'In a moment of haste, some French writers have interpreted the condemnations in the Syllabus as a condemnation of the principles of $1789 . \ldots$. But is it well, he goes on to ask, 'to take for granted, and to make us who are at a distance believe, that the principles of 1789 are such as the theology and morality of the Christian Church must condemn? We would desire to believe, if we can, that these principles, even if they bear the marks of a period of excitement rather than of calm and measured thought, are nevertheless in some way reconcilable with the great laws of political morality which lie at the foundations of human society and are consecrated by the sanction of the Christian world. I should be sorry to believe that there is anything indelibly impressed on the political order of the great French people which is at variance with the intellectual and moral system of the Catholic Church. ${ }^{32}$ To avoid the accusation of speaking for the French in a matter of their own interest, Manning supported his argument instead by quoting from two French Catholic writers, Prince Albert de Broglie and Abbe Leon Godard, a professor of ecclesiastical history at the seminary at Langres. De Broglie's purpose, in an article earlier that same year in the Revue des Deux Mondes, ${ }^{3}$ had been to explore the grounds of compatibility and conflict between the Revolution and the Catholic Church, and his conclusion was that no incompatibility existed except in so far as the heirs of the Revolution claimed for it the character not only of a political system, but of a religion, and exacted from the Church not merely loyalty but unquestioned belief.

The argument of Abbe Godard, published in 1863 in a work entitled Les Principes de ' 89 et la Doctrine Catholique went a good deal further than de Broglie. His purpose, according to Manning, was, 'if possible, to remove the supposed contrariety between the principles of " 89 and the principles of the Catholic Church: a wise and charitable purpose to which we are all daily invited, I may even say provoked, by the alternate tones of perplexity and of challenge which come up from friends and foes. ${ }^{34}$ Godard's book, which Manning was careful to point out bore a Roman imprimatur, concluded with the author's assertion, quoted approvingly by Manning, that the 'principles of ' $89 \ldots$ do not contradict any decision of the Catholic, Apostolic and Roman
Church. . . . The tactics of our adversaries,' Godard continued, 'are Church. . . ' a complete rejection of ' 89 , in order at once to accuse to draw desire to set up again the ancien regime, with all its abuses, us of a desire to set up existing laws. These tactics we will baffle, and and to overthrow the existing laws. These tactics we will baffe, and we will not abandon an to hold. ${ }^{35}$ To which Manning appended his own conclusion:

The work of M. Leon Godard will go a long way to relieve the fears and to The work of M. Leon Godar of certain politicians and political writers in rectify the misconceptions of certain politicians and political writers in not by any individual, but by the Holy See, need cause the fears-I would not by to use a familiar word and say the scare-which in some quarters venture to use a forst.

It is important not to assume that Manning's defense of the compatiility of Catholicism with the liberal state was merely a ploy to disarm bility of Catholicism with the liberal state was merely a ploy to disarm freedom of the Council. Manning was, indeed, concerned to avoid freedom of interference. But his efforts to distance himself from the any such interference. But his efforts to distance himself from the intransigence of French primarily a matter of extrinsic or instrumental policy to protect the Council from interference. There was, on the contrary, an internal, intrinsic connection between the activism on behalf of a more Christian society which Manning wished Catholics to undertake in the new political environment of the desacralized, democratic political order, and his enthusiastic support for papal authority in the Church.

Authority, as important as it was to Manning for the unity and identity of the Church, did not exist solely so the Church could preserve its integrity in an unbelieving and hostile world. What is really most original and stimulating about Manning's ultramontanism in its political aspect is his vision of the significance of infallibility for the mission of the Church to the new political world in which it found itself.

Manning must be taken seriously, and was not merely indulging in rhetoric, when he advanced the argument, in the 1867 pastoral already cited, that the Council, as a manifestation of 'the supreme spiritual independence of the Church convened by its head . . . freely legislating for the whole Catholic unity, must appeal to every pure instinct of Christians., ${ }^{37}$ The effect of that appeal, Manning was convinced, would not be on governments directly, but rather on the masses of the people..$^{38}$ Just how powerful he thought the appeal of the Church's witness to authority and unity must be to the world at large, Manning made clear at the Council itself. In his great speech in the Council Hall of May 23,1870 in support of the definition of papal infallibility, a speech which the English historian of the Council has called 'one of the triumphs of Manning's life,' Manning offered the following argument in favour of the definition and against those who argued that the 
time was not opportune for a definition because it would discourage conversion. He appealed to his own status as the only convert at the Council to make the claim that 'far from proving an obstacle to the return of England to the Catholic Church,' as some had maintained 'the papal infallibility would be a powerful attraction for those outside the Church. ... . So far as England is concerned, the definition will more than anything else promote conversions, and the return of the country to the Faith.' This was predictable, if overly sanguine rhetoric, but what followed it must have sounded strangely in the ears of the Council Fathers. 'The progress of Catholicism in England,' Manning argued, 'is to be measured not so much by the number of actual conversions, as by the progressive penetration, constant and visible, of the whole English people, by Catholic ideas and Catholic truth, and the change of mental attitude that is being wrought thereby. ${ }^{39}$

What the Council Fathers from Catholic countries must have made of this part of Manning's Address is difficult to say, for his argument makes no sense at all in relation to the Catholic 'thesis': i.e., of a State which officially recognized, and, in spiritual matters, deferred to the authority of the Church as enunciated by the Roman Pontiff. Rather the very ideas of a 'progressive penetration' of 'the whole people' to effect a 'change of mental attitude' assumes that the Church is functioning in the social and political context of a State religiously neutral where popular opinion will have its effect on public policy in matters of concern to Catholics. Manning's argument envisions, in other words, the political culture of Britain. It is precisely because the Church could have this effect on public opinion and, by implication, on public policy in a State like Britain, that it was necessary for the Church to speak definitively and unequivocally through the infallible voice of the Roman Pontiff.

\section{NOTES}

' Manning, The Temporal Power of the Vicar of Jesus Christ (London: Burns and Lambert, 1862)

p. 26. A collection of sermons and lectures delivered in 1860-1861.
2 Manning, The Temporal Power of the Vicar of Jesus Christ, pp. 26-27.

3 Manning, Temporal Power, 36, 45 .

' Manning, 'Inaugural Address to the Academia of the Catholic Religion,' Session 1868-9, in Manning, Miscellanies, (London: Burns and Oates, 1877), vol. I, p. 276.

5 Manning, The Temporal Power of the Vicar of Jesus Christ (London: Burns and Lambert, 1862), p. xxix.

6 Ibid., p. xliii.

? Ibid., p. 72 .

8 Ibid., p. 72 .
Ibid., p. 130 .

10 Ibid., p. 730 . 73 .

"Ibid,, p. 74. What did Manning mean by this prediction? His explication, while not terribly illuminating, at least provides some indication of the order of reality which he had in mind: 'How shall we interpret this strong prophecy? The facts of the modern world give us the interpretation. Natural society, which when once subjugated by the providence of God became Christian Europe, will again break forth. It will resume its powers of unregenerate and unchastened will and passion, and men will constitute society, not God. Christin Europe is God's society, but society without faith orn of the Spirit is Spirit' [In 3:6]. There is an irreconcilable conflict between the two principles. Do not you think that $\mathrm{I}$ am extravagant and going out of all bounds and measure in what I say. What, I ask you was the first French Revolution but pagan revival? What was the Revolution of 1848 but the old heathenism, which had been subdued in Italy and Rome, and held under by the Christian order of Eurst God?

This is the end to which the fair structure of Christian Europe seems tending. I do not say it will ever arrive at this end, for the providence of God may indeed change its course. Of this I know nothing. . . . If 1 see certain great anti-Christian principles in motion throughout Europe, I need no inspiration, no gifts of prophecy, their resull, hal sciety of man without God in the world." pp. 75-76.

of the natural son: The English Catholic Church in the Nineteenth Century (Clarendon Press, Oxford, 1984), pp. 264 seq.

Manning, 'On the Subjects Proper to the Academia,' in Miscellanies, vol. I, pp. 88-89.

i. Manning in Miscellanies, vol. I, pp. 182-183.

is Ibid., p. 81 .

Ibid., p. 83

anning, 'Inaugural Address,' in Miscellanies, vol. I, p. 183.

Ibid., p. $185-187$

Manning, England and Christendom (London: Longmans, Green and Co.: 1867), pp. xxxix, xliii. Ibid., pp. xcri-ii.

Ibid., p. xcviil.

Ibid., p. xcvili.

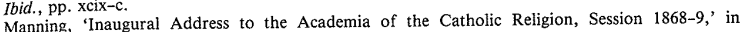
Miscellanies, vol. 1, p. 265

2s Ibid., pp. 261 .

${ }^{26}$ Ibid., p. 291.

Ibid., p. 291. (London: Longmans, Green and Co., 1867), pp. 98-99.

${ }_{30}$ Ibid., p. 101

Ibid, p. 90.

32 Manning, The Oecumenical Council and the Infallibility of the Roman Pontiff: A Pastoral Letter

o the Clergy (London: Longmans, Green and Co., 1869), pp. 17-18.

Albert de Broglie, 'Le Christianisme et la Societe,' in Revue des Deus Mondes, Feb., 1869.

Aanning in The Oecumenical Council ...., p. 22.

Ibid., pp. $23-4$

I7 Manning Centenary of Saint Peter, p. 96. N.B.: 'Christians' without differentiation. When Manning meant Catholics only, he said so.

${ }_{38}$ Ibid., p. 96.

${ }^{39}$ Cuthbert Butier, The Vatican Council (Longmans, Green and Co.: London, 1930), vol. II, p. 50 (my emphasis) 